\title{
Erratum to: Future projections of the surface heat and water budgets of the Mediterranean Sea in an ensemble of coupled atmosphere-ocean regional climate models
}

\author{
C. Dubois $\cdot$ S. Somot $\cdot$ S. Calmanti $\cdot$ A. Carillo $\cdot$ M. Déqué $\cdot$ A. Dell'Aquila $\cdot$ \\ A. Elizalde $\cdot$ S. Gualdi · D. Jacob $\cdot$ B. L'Hévéder $\cdot$ L. Li $\cdot$ P. Oddo • \\ G. Sannino $\cdot$ E. Scoccimarro $\cdot$ F. Sevault
}

Published online: 10 February 2012

(C) Springer-Verlag 2012

\section{Erratum to: Clim Dyn}

DOI 10.1007/s00382-011-1261-4

Unfortunately, one of the author's names has been misspelt in the original publication of the article. The author's name should read “A. Dell' Aquila."

The complete author group is provided below:

C. Dubois - S. Somot - S. Calmanti · A. Carillo .

M. Déqué · “A. Dell'Aquila” · A. Elizalde · S. Gualdi ·

D. Jacob · B. L’Hévéder · L. Li · P. Oddo · G. Sannino ·

E. Scoccimarro $\cdot$ F. Sevault

The online version of the original article can be found under doi:10.1007/s00382-011-1261-4.

C. Dubois $(\bowtie) \cdot$ S. Somot · M. Déqué $\cdot$ F. Sevault CNRM-GAME, Météo-France, CNRS, Toulouse, France

e-mail: clotilde.dubois@cnrm.meteo.fr

S. Calmanti · A. Carillo · A. Dell'Aquila · G. Sannino ENEA, Rome, Italy

A. Elizalde · D. Jacob

Max Planck Institute for Meteorology, Hamburg, Germany

S. Gualdi $\cdot$ P. Oddo $\cdot$ E. Scoccimarro

INGV, Bologna, Italy

B. L'Hévéder · L. Li

Laboratoire de Météorologie Dynamique, Paris, France 